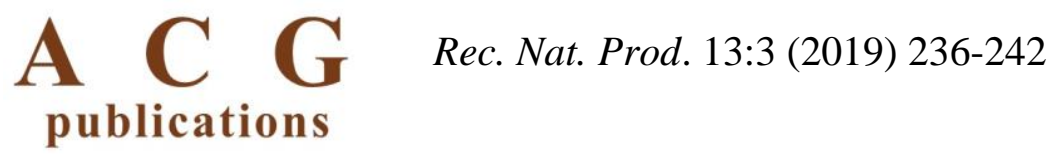

records of natural products

\title{
Composition of the Essential Oils of Two Endemic Helichrysum Species in Turkey
}

\author{
Mine Kürkçüoğlu $\odot^{* 1}$, Hale Gamze Ağalar ${ }^{1}$, Ahmet Aksoy $\odot^{2}$, \\ and Kemal Hüsnü Can Başer $\odot^{3}$
}

\author{
${ }^{1}$ Department of Pharmacognosy, Faculty of Pharmacy, Anadolu University, 26470 Eskişehir, Türkiye \\ ${ }^{2}$ Department of Biology, Faculty of Science, Akdeniz University, Antalya, Türkiye \\ ${ }^{3}$ Department of Pharmacognosy, Faculty of Pharmacy, Near East University, Lefkoşa
}

(Nicosia), Turkish Republic of Northern Cyprus

(Received Received June 10, 2018, Revised July 30, 2018; Accepted August 09 2018)

\begin{abstract}
The aerial parts of Helichrysum noeanum Boiss. and $H$. chionophilum Boiss. et Balansa were hydrodistilled for $3 \mathrm{~h}$ using a Clevenger-type apparatus. The essential oils were analyzed by GC-FID and GCMS, simultaneously. The main constituents were identified as hexadecanoic acid (25.3\%), dodecanoic acid (17.8\%), tetradecanoic acid (13.7\%), and decanoic acid (4.2\%) for H. noeanum. Decanoic acid (18.7\%), tetradecanoic acid (16.9\%), dodecanoic acid (13.8\%), hexadecanoic acid (12.2\%) and hexahydrofarnesyl acetone (3.2\%) were found to be the major compounds for H. chionophilum. Several reports have been encountered in the literature dealing with the oil composition of several Helichrysum species. To the best of our knowledge, the essential oil of $H$. chionophilum has not previously been investigated.
\end{abstract}

Keywords: Helichrysum noeanum; H. chionophilum; essential oil; GC; GC-MS. (C) 2019 ACG Publications. All rights reserved.

\section{Introduction}

The genus Helichrysum Mill. belongs to the Asteraceae consists of approximately 600 species widespread throughout the world. Its name was derived from the Greek words helios (sun) and chrysos (gold) which is appropriate considering the attractive yellow flowers displayed by several species [1]. Most species are indigenous to South Africa (approximately 250 species), some are spontaneous in Europe (16 species) and in the Mediterranean areas. Some species are found in South-west Asia, southern India, Sri Lanka and Australia [2]. In Turkey, this genus is represented by 30 taxa. Sixteen of them are endemic in Turkey and Helichrysum species are known as "altın çiçeği," altınotu," and "kovanotu" [3].

Members of the genus Helichrysum are aromatic herbs or dwarf perennial shrubs [2]. The species have been used in folk medicine for at least 2000 years against gall bladder disorders [4]. The

\footnotetext{
* Corresponding author: E-mail: minekurkcuoglu@gmail.com 
species are used in the folk medicines of Europe and Africa as herbal teas for the treatment of cough and respiratory problems, digestive disorders, skin inflammation, fever, wound care and pain with analgesic effect. Furthermore, the species are often used to treat tuberculosis and for applications as cardiotonic, diuretic and anti-diarrheal remedies [2,5]. In Turkey, several Helichrysum species are utilized in folk medicine for removing the kidney stones and as diuretics [4]. Herbal teas are consumed for various biological properties including anti-inflammatory, antioxidant and antimicrobial activity in Turkey and various parts of the world [6].

The genus has an important source of secondary metabolites such as flavonoids, phytocannabinoids, triterpenoids, diterpenoids, steroids, organic acids, phloroglucinol and acetophenone derivatives and aromatic species have been studied for their content of essential oils [610]. Several reports have been encountered in the literature dealing with the oil composition of several Helichrysum species; these include $H$. bracteiferum (DC.) Humbert [11], $H$. picardii Boiss. \& Reuter [12,13], H. taenari Rothm. and H. stoechas (L.) Moench ssp. barrelieri (Teno) Nyman [13] and $H$. amorginum Boiss. \& Orph. and H. italicum (Roth) G. Don [14], H. cordifolium DC., H. hypnoides (DC.) R.Vig. et Humbert, H. rusillonii Hochr. [15], H. dasyanthum (Willd.) Sweet, H. excisum (Thunb.) Less and $H$. felinum Less and $H$. petiolare Hilliard and Burtt [16], H. forsskahlii (Gmel) Hilliard et Burt [17], H. plicatum DC. (H. plicatum DC. subsp. plicatum, H. plicatum DC. subsp. polyphyllum (Ledeb) P.H.Davis \& Kupicha and H. plicatum DC. subsp. isauricum Parolly) [18], $H$. conglobatum (Viv.) Steudel. [19], H. noeanum Boiss. [20].

Helichrysum species have been known since ancient times due to a large distribution and diversity [21]. Helichrysum is a rather variable genus, since a number of modifications strongly affect the morphological aspect of its species and consequently the taxonomic determination is often uncertain [22]. Along with the taxonomically recognized Helichrysum species a significant number of evolved hybrids are also found. The individual morpho-anatomical characteristics of these hybrids can be deceiving and can lead to wrong assignments to recognized taxa. The high degree of genotypic variability, observed in a number of Helichrysum species, is rejected in the biochemical variability which is usually studied at the levels of terpene composition and isozyme variation. The volatile constituents, especially monoterpenes, can be used for taxonomic purposes [23].

Among the large number of phytoproducts, isolated from Helichrysum species, essential oil has an important biological role. Since, the plant is characterized by a high level of genetic and metabolic polymorphism forming as a response to environmental conditions and geographic location, different chemotypes of its essential oils can be expected [24].

In the literature, there are a few published data on $H$. noeanum and $H$. chionophilum. The essential oil composition of the aerial parts [25] and flavonoids of capitula and leafy stems [26] of $H$. noeanum were reported. 3,5-Dihydroxy-6,7,8-trimethoxyflavone, apigenin, kaempferol, naringenin, helichrysin A, helichrysin B, isosalipurposide, naringenin 4'-glucoside, apigenin 7-glucoside, and astragalin were identified in the capitula whereas kaempferol, astragalin, and quercetin 3-glucoside were isolated from the leafy stems [26]. Elkıran et al. [25] reported the major compounds as $\gamma$ gurjunene $(11.06 \%)$, spathulenol $(9.90 \%)$, alloaromadendrene $(7.53 \%), \beta$-caryophyllene $(7.10 \%)$ in the essential oil of aerial parts. No study has been encountered on phytochemistry of $H$. chionophylum.

These endemic species were evaluated for their possible biological activities by limited studies. Tepe et al. [27] evaluated in vitro antioxidant activities of Helichrysum noeanum and $H$. chionophilum methanol extracts. Eroglu et al. [28] found the genotoxic activities of $H$. noeanum methanol extracts by inducing the formation of micronuclei and decreasing the mitotic and replication indexes. It was published by Albayrak et al. [4] that $H$. noeanum extract showed significant antimicrobial activity.

In the present study, endemic species Helichrysum noeanum and $H$. chionophilum were studied for their volatile compound characterizations. H. noeanum and H. chionophilum are locally known as "gulazar and yaylahencecaligi", resp. [29]. The essential oil composition of $H$. chionophilum was characterized for the first time. 


\section{Materials and Methods}

\subsection{Plant Material}

Aerial parts of Helichrysum noeanum (A) and H. chionophilum (B) were collected while flowering from Ankara: Bala-Kaman on June 30, 2005 and Kayseri: Arslantaş plateau on August 14, 2007, resp. Voucher specimens were kept at the herbarium of the Faculty of Science (Aksoy 2100 and Aksoy 2089) resp., Akdeniz University (Turkey).

\subsection{Isolation of the Essential Oils}

The dried aerial parts of Helichrysum noeanum and $H$. chionophilum were subjected to hydrodistillation for $3 \mathrm{~h}$ using a Clevenger type apparatus.

\subsection{GC and GC-MS Conditions}

The oils were analyzed by capillary Gas Chromatography (GC) and Gas ChromatographyMass Spectrometry (GC-MS) using a Agilent GC-MSD system (Mass Selective Detector-MSD) (Agilent Technologies Inc., Santa Clara, CA).

\subsubsection{GC-MS Analysis}

The GC-MS analysis was carried out with an Agilent 5975 GC-MSD system according to the literature [15]. Innowax FSC column $(60 \mathrm{~m} \times 0.25 \mathrm{~mm}, 0.25 \mu \mathrm{m}$ film thickness) was used with helium as carrier gas $\left(0.8 \mathrm{~mL} / \mathrm{min}\right.$.). GC oven temperature was kept at $60^{\circ} \mathrm{C}$ for $10 \mathrm{~min}$ and programmed to $220^{\circ} \mathrm{C}$ at a rate of $4{ }^{\circ} \mathrm{C} / \mathrm{min}$, and kept constant at $220^{\circ} \mathrm{C}$ for $10 \mathrm{~min}$ and then programmed to $240^{\circ} \mathrm{C}$ at a rate of $1{ }^{\circ} \mathrm{C} / \mathrm{min}$. Split ratio was adjusted $40: 1$. The injector temperature was at $250^{\circ} \mathrm{C}$. MS were taken at $70 \mathrm{eV}$. Mass range was from $\mathrm{m} / \mathrm{z} 35$ to 450 .

\subsubsection{GC Analysis}

The GC analysis were done according to the literature [15] was carried out using an Agilent $6890 \mathrm{~N}$ GC system. In order to obtain same elution order with GC-MS, simultaneous injection was done by using same column and an appropriate operational conditions. FID temperature was $300^{\circ} \mathrm{C}$.

\subsection{Identification of compounds}

The components of essential oils were identified by comparison of their mass spectra with those in the Baser Library of Essential Oil Constituents, Adams Library [30], MassFinder Library [31], Wiley GC-MS Library [32] and confirmed by comparison of their retention indices. These identifications were accomplished by comparison of retention times with authentic samples or by comparison of their relative retention index (RRI) to a series of $n$-alkanes. Alkanes were used as reference points in the calculation of relative retention indices (RRI) [33]. Relative percentage amounts of the separated compounds were calculated from FID chromatograms. The results of analysis are shown in Table 1.

\section{Results and Discussion}

The present work reports the composition of the essential oils of Helichrysum noeanum and $H$. chionophilum, endemic in Turkey. The aerial parts of $H$. noeanum and $H$. chionophilum were water distilled for $3 \mathrm{~h}$ using a Clevenger-type apparatus. The yields of $H$. noeanum and $H$. chionophilum essential oils were $0.04 \%$ and $0.07 \%$, resp. The essential oils were analyzed by GC-FID and GC-MS simultaneously. Forty one and forty-seven volatile compounds were identified in both of the aerial parts essential oils representing $83.2 \%$ and $84.6 \%$ of the total oils, respectively. 
Table 1. The composition of the essential oils of Helichrysum noeanum and H. chionophilum

\begin{tabular}{|c|c|c|c|c|c|}
\hline $\mathbf{R R I}^{\mathbf{a}}$ & $\mathbf{R R I}^{\mathbf{b}}$ & Compounds & $\begin{array}{l}\mathbf{A} \\
\%\end{array}$ & $\begin{array}{l}\text { B } \\
\%\end{array}$ & IM \\
\hline 1400 & $1400^{\mathrm{k}, \mathrm{m}}$ & Tetradecane & - & 0.1 & $t_{R}$ \\
\hline 1401 & $1400^{\mathrm{c}}, 1391^{\mathrm{d}}$ & Nonanal & - & 0.2 & MS \\
\hline 1497 & $1497^{c}, 1488^{\mathrm{e}}$ & $\alpha$-Copaene & 0.6 & 0.1 & MS \\
\hline 1500 & $1500^{\mathrm{m}}$ & Pentadecane & - & 0.1 & $t_{R}, M S$ \\
\hline 1506 & $1506^{\mathrm{c}}, 1496^{\mathrm{d}}$ & Decanal & - & 0.3 & MS \\
\hline 1553 & $1543^{\mathrm{d}}$ & Italicene & - & 0.3 & $t_{R}, M S$ \\
\hline 1562 & $1562^{\mathrm{k}, \mathrm{n}}$ & Octanol & - & 0.1 & $\mathrm{t}_{\mathrm{R}}, \mathrm{MS}$ \\
\hline 1612 & $1612^{\mathrm{c}}, 1598^{\mathrm{d}}$ & $\beta$-Caryophyllene & 0.5 & 1.2 & $t_{R}, M S$ \\
\hline 1628 & $1620^{\mathrm{d}}$ & Aromadendrene & - & 0.2 & MS \\
\hline 1661 & $1664^{\mathrm{d}}$ & $\alpha$-Himachalene & - & 0.2 & MS \\
\hline 1664 & $1656^{\mathrm{d}}$ & Nonanol & - & 0.3 & MS \\
\hline 1687 & $1663^{\mathrm{e}}, 1667^{\mathrm{d}}$ & $\alpha$-Humulene & 0.7 & 0.2 & $\mathrm{t}_{\mathrm{R}}, \mathrm{MS}$ \\
\hline 1704 & $1704^{\mathrm{f}, \mathrm{k}}, 1689^{\mathrm{g}}$ & $\gamma$-Muurolene & 0.6 & - & MS \\
\hline 1711 & $1709^{\mathrm{d}}$ & $\gamma$-Himachalene & - & 0.2 & MS \\
\hline 1719 & $1719^{\mathrm{k}}$ & Borneol & $\mathrm{t}$ & 0.2 & $t_{R}, M S$ \\
\hline 1722 & $1712^{\mathrm{d}}$ & Dodecanal & - & 0.1 & $t_{R}, M S$ \\
\hline 1729 & $1723^{\mathrm{d}}$ & $\beta$-Himachalene & - & 0.1 & MS \\
\hline 1740 & $1740^{\mathrm{f}}, 1723^{\mathrm{g}}$ & $\alpha$-Muurolene & 0.4 & $\mathrm{t}$ & MS \\
\hline 1744 & $1725^{\mathrm{d}}$ & $\alpha$-Selinene & 0.1 & - & MS \\
\hline 1765 & $1748 \mathrm{~d}$ & (E)-2-Undecenal & - & 0.4 & MS \\
\hline 1772 & $1773^{\mathrm{f}, \mathrm{k}}, 1755^{\mathrm{g}}$ & $\delta$-Cadinene & 0.7 & 0.1 & $\mathrm{t}_{\mathrm{R}}, \mathrm{MS}$ \\
\hline 1776 & $1776^{\mathrm{f}, \mathrm{k}}, 1763^{\mathrm{g}}$ & $\gamma$-Cadinene & 0.6 & 0.1 & MS \\
\hline 1786 & $1774^{\mathrm{d}}$ & ar-Curcumene & - & 0.1 & MS \\
\hline 1811 & $1769^{\mathrm{d}}$ & $\alpha$-Cadinene & 0.2 & - & MS \\
\hline 1853 & $1835^{\mathrm{d}}, 1849^{\mathrm{g}, \mathrm{k}}$ & cis-Calamenene & 0.3 & - & MS \\
\hline 1868 & $1855^{\mathrm{d}}$ & (E)-Geranyl acetone & 0.2 & 0.6 & $\mathrm{t}_{\mathrm{R}}, \mathrm{MS}$ \\
\hline 1882 & $1884^{\mathrm{p}}$ & $\begin{array}{l}\text { 1-Isobutyl 4-isopropyl-2,2-dimethyl } \\
\text { succinate }\end{array}$ & 0.2 & 0.6 & MS \\
\hline 1941 & $1921^{\mathrm{d}, \mathrm{g}}, 1941^{\mathrm{f}}$ & $\alpha$-Calacorene & 0.2 & - & MS \\
\hline 1965 & $1866^{\mathrm{d}}, 1972^{\mathrm{p}}$ & Dodecanol & 0.2 & - & MS \\
\hline 2008 & $1986^{\mathrm{d}}, 2008^{\mathrm{c}, \mathrm{p}}$ & Caryophyllene oxide & 1.4 & 0.3 & $t_{R}, M S$ \\
\hline 2041 & $2015^{\mathrm{d}}, 2041^{\mathrm{d}}$ & Pentadecanal & - & 0.4 & MS \\
\hline 2045 & $2045^{\mathrm{g}}$ & Humulene epoxide-I & 0.4 & - & MS \\
\hline 2071 & $2047^{\mathrm{d}, \mathrm{g}}, 2069^{\mathrm{f}}$ & Humulene epoxide-II & 1.5 & 0.2 & MS \\
\hline 2073 & $2044^{\mathrm{d}}$ & $\beta$-Caryophyllene alcohol & 0.4 & 0.5 & MS \\
\hline 2080 & $2074^{\mathrm{d}}$ & 1, 10-diepi- Cubenol & $\mathrm{t}$ & - & MS \\
\hline 2081 & $2081^{\mathrm{g}}$ & Humulene epoxide-III & 0.1 & - & MS \\
\hline 2084 & $2057^{\mathrm{d}}$ & Octanoic acid & - & 0.2 & MS \\
\hline 2131 & $2131^{\mathrm{c}}, 2124^{\mathrm{e}}$ & Hexahydrofarnesyl acetone & 1.7 & 4.9 & $t_{R}, M S$ \\
\hline 2162 & $2146^{\mathrm{r}}$ & Muurola-4,10(14) dien-1-ol & 0.3 & - & MS \\
\hline 2174 & $2159^{\mathrm{d}}$ & Nonanoic acid & 0.4 & 0.8 & MS \\
\hline 2191 & $2187^{\mathrm{f}}, 2165^{\mathrm{g}}$ & T-Cadinol & 0.6 & 0.4 & MS \\
\hline 2204 & $2205^{\mathrm{c}}, 2164^{\mathrm{d}}$ & Thymol & - & 0.1 & $t_{R}, M S$ \\
\hline 2205 & $2196^{\mathrm{p}}$ & Clovenol & 0.2 & 0.9 & $\mathrm{t}_{\mathrm{R}}, \mathrm{MS}$ \\
\hline 2209 & $2209^{\mathrm{f}, \mathrm{p}}, 2140^{\mathrm{h}}$ & T-Muurolol & 0.2 & - & MS \\
\hline 2219 & $2219^{\mathrm{r}}$ & $\delta$-Cadinol & 0.2 & - & MS \\
\hline 2246 & $2246^{\mathrm{c}}, 2211^{\mathrm{d}}$ & Carvacrol & 0.5 & 2.1 & $t_{R}, M S$ \\
\hline 2255 & $2255^{\mathrm{f}}, 2227^{\mathrm{d}, \mathrm{g}}$ & $\alpha$-Cadinol & 0.8 & - & $\mathrm{t}_{\mathrm{R}}, \mathrm{MS}$ \\
\hline 2256 & $2233^{\mathrm{d}}$ & Cadalene & - & 0.2 & MS \\
\hline 2286 & $2274^{\mathrm{d}}$ & Decanoic acid & 4.2 & 18.9 & MS \\
\hline 2300 & $2300^{\mathrm{m}}$ & Tricosane & 0.7 & - & $\mathrm{t}_{\mathrm{R}}, \mathrm{MS}$ \\
\hline 2324 & $2324^{\mathrm{g}}$ & Caryophylladienol II & - & 0.3 & MS \\
\hline 2353 & $2389^{\mathrm{g}}$ & Caryophyllenol I & - & 0.8 & MS \\
\hline 2392 & $2392^{\mathrm{c}, \mathrm{d}}$ & Caryophyllenol II & - & 0.8 & MS \\
\hline 2396 & $2396^{\mathrm{p}}$ & $\gamma$-Dodecalactone & 0.3 & 0.5 & MS \\
\hline 2399 & $2391^{\mathrm{d}}$ & Undecanoic acid & 1.1 & 0.3 & $t_{R}, M S$ \\
\hline
\end{tabular}




\begin{tabular}{cclccc}
\hline \multicolumn{2}{l}{ Table 1 Continued.. } & & & & \\
\hline 2400 & $2400^{\mathrm{m}}$ & Tetracosane & 0.6 & - & $\mathrm{t}_{\mathrm{R}}, \mathrm{MS}$ \\
2500 & $2500^{\mathrm{m}}$ & Pentacosane & 3.8 & - & $\mathrm{MS}$ \\
2503 & $2487^{\mathrm{d}}, 2503^{\mathrm{g}}$ & Dodecanoic acid & $\mathbf{1 7 . 8}$ & $\mathbf{1 3 . 9}$ & $\mathrm{t}_{\mathrm{R}}, \mathrm{MS}$ \\
2617 & $2617^{\mathrm{d}}$ & Tridecanoic acid & - & 0.7 & $\mathrm{MS}$ \\
2696 & $2696^{\mathrm{c}}, 2687^{\mathrm{d}}$ & Tetradecanoic acid & $\mathbf{1 3 . 7}$ & $\mathbf{1 7 . 0}$ & $\mathrm{t}_{\mathrm{R}}, \mathrm{MS}$ \\
2819 & $2822^{\mathrm{d}}$ & Pentadecanoic acid & 1.0 & 1.6 & $\mathrm{MS}$ \\
2859 & $2765^{\mathrm{p}}$ & $\gamma$-Palmitolactone & 0.5 & 0.7 & $\mathrm{MS}$ \\
2931 & $2931^{\mathrm{c}, \mathrm{g}}, 2913^{\mathrm{d}}$ & Hexadecanoic acid & $\mathbf{2 5 . 3}$ & $\mathbf{1 2 . 3}$ & $\mathrm{MS}$ \\
\hline
\end{tabular}

RRI $\mathrm{a}^{\mathrm{a}}$; Relative retention indices calculated against $\mathrm{n}$-alkanes. \%; calculated from the FID chromatograms. RRI ${ }^{\mathrm{b}}$ : : RRI from literature (c [34], d [35], e [36], f [37], g [38], h [39], k [40], m [41], n [42], p [43], r [44]) for polar column values; tr; Trace (<0.1 \%). Identification method (IM): $t_{R}$, identification based on the retention times $\left(t_{R}\right)$ of genuine compounds on the HP Innowax column; MS, identified on the basis of computer matching of the mass spectra with those of the in-house Baser Library of Essential Oil Constituents, Adams, MassFinder and Wiley libraries and comparison with literature data. A: Helichrysum noeanum Boiss. B: and H. chionophilum Boiss. et Balansa

Aerial parts of Madagascarian H. bracteiferum (DC.) Humbert: 1,8-cineole (24.8\%) and $\alpha$ humulene (10.1\%), H. cordifolium DC.: $\beta$-caryophyllene $(46.4 \%)$ and $\alpha$-humulene $(10.9 \%), H$. hypnoides (DC.) R.Vig. et Humbert: 1,8-cineole (51.5\%) and $\alpha$-terpineol (13.2\%), H. rusillonii Hochr.: $\beta$-caryophyllene $(29.5 \%)$ and 1,8-cineole $(11.1 \%)$ were reported as main constituents [15]. Selina-5,11-diene (45.3\%), $\delta$-3-carene (7.8\%), 1.8-cineole (4.2\%) and $\beta$-caryophyllene $(4.9 \%)$ were reported as main constituents of the aerial parts of the H. forsskahlii (Gmel) Hilliard et Burt oil from Saudi Arabia [17].

Essential oil from South African H. dasyanthum (Willd.) Sweet yielded 1,8-cineole (20.6\%), $\alpha$-pinene (16.6\%) and $\beta$-caryophyllene (13.3\%); H. excisum (Thunb.) Less: 1,8-cineole (34.0\%), viridiflorol (18.2\%); $H$. felinum Less: $\beta$-caryophyllene (27.6\%), $\alpha$-humulene $(9.4 \%)$ and alloaromadendrene $(7.3 \%)$ and $H$. petiolare Hilliard and Burtt: 1,8-cineole $(22.4 \%), \beta$-caryophyllene $(14.0 \%)$ and $p$-cymene (9.8\%) were reported as main constituents [16].

High abundance of fatty acids and their esters (24.9-70.8\%) was detected in the herb volatiles of $H$. plicatum subsp. polyphyllum and H. plicatum subsp. isauricum. T-Cadinol (7.9\%) was reported as main constituent of the aerial parts of the Helichrysum plicatum DC. subsp. plicatum from Turkey. The inflorescences of Helichrysum subspecies were found to be rich in monoterpenes (15.0-93.1\%), fatty acids $(0.1-36.3 \%)$ and sesquiterpenes (1.1-25.5\%). The inflorescence volatiles of $H$. plicatum subsp. isauricum were distinguished by predomination of monoterpene hydrocarbons $(93.1 \%)$ with fenchene (88.3\%) as the major constituent [18].

The main components of the $H$. conglobatum oil from Cyprus were $\beta$-caryophyllene (14.6\%), $\gamma$-curcumene (14.1\%), hexadecanoic acid (13.5\%) and tetradecanoic acid (7.5\%) [19].

In our study, the main constituents were identified as hexadecanoic acid (25.3\%), dodecanoic acid (17.8\%), tetradecanoic acid (13.7\%), and decanoic acid (4.2\%) for $H$. noeanum. Decanoic acid (18.7\%), tetradecanoic acid (16.9\%), dodecanoic acid (13.8\%), hexadecanoic acid (12.2\%) and hexahydrofarnesyl acetone (3.2\%) were found to be the major compounds for H. chionophilum. Elkiran et al. [20] have previously reported $\gamma$-Gurjunene (11.06\%), spathulenol (9.90\%), alloaromadendrene $(7.53 \%)$ and $\beta$-caryophyllene (7.10\%) as main constituents in the essential oil of H. noeanum from Ankara.

To the best of our knowledge, the essential oil of $H$. chionophilum has not chemically been investigated previously.

\section{Acknowledgments}

This study was financially supported by Anadolu University Scientific Research Projects Commission under the grant no: 1805 S209.

\section{ORCID}

Mine Kürkçüoğlu: 0000-0002-9375-0294

Hale Gamze Ağalar: 0000-0003-4826-5975

Ahmet Aksoy: 0000-0002-9696-7122

Kemal Hüsnü Can Başer: 0000-0003-2710-0231 


\section{References}

[1] A. C. U. Lourens, A. M. Viljoen, and F. R. van Heerden (2008). South African Helichrysum species: a review of the traditional uses, biological activity and phytochemistry, J. Ethnopharmacol. 119, 630-652.

[2] S. Giovanelli, M. De Leo, C. Cervelli, B. Ruffoni, D. Ciccarelli and L. Pistelli (2018). Essential oil composition and volatile profile of seven Helichrysum species grown in Italy, Chem. Biodivers. 15, doi: 10.1002/cbdv.201700545.

[3] J. C. Chalcat and M. M. Özcan (2006). Composition of the essential oil of Helichrysum chasmolycicum growing wild in Turkey, J. Med. Food. 9(2), 287-289.

[4] S. Albayrak, A. Aksoy, O. Sagdic and E. Hamzaoğlu (2010). Compositions, antioxidant and antimicrobial activities of Helichrysum (Asteraceae) species collected from Turkey, Food Chem. 119, 114-122.

[5] R. V. B. Reidel, P. Cioni, C. Cervelli, B. Ruffoni and L. Pistelli (2016). Essential oil composition from three Helichrysum species, Planta Med. 82, doi:10.1055/s-0036-1596804.

[6] S. Albayrak, A. Aksoy, O. Sağdıç and Ü. Budak (2010). Phenolic compounds and antioxidant and antimicrobial properties of Helichrysum species collected from eastern Anatolia, Turkey, Turk. J. Biol. 34, 463-473.

[7] I. I. Tatlı, S. Sahpaz, E. Kupeli Akkol, F. Martin-Nizard, B. Gressier, N. Ezer and F. Bailleul (2009). Antioxidant, anti-inflammatory and antinociceptive activities of Turkish medicinal plants, Pharm. Biol. 47(9), 916-921.

[8] F. Pollastro, L. De Petrocellis, A. Schiano-Moriello, G. Chianese, H. Heyman, G. Appendino and O. Taglialatela-Scafati (2018). Reprint of: amorfrutin-type phytocannabinoids from Helichrysum umbraculigerum, Fitoterapia 126, 35-39.

[9] O. K. Popoola, J. L. Marnewick, F. Rautenbach, E. I. Iwnoha and A. A. Hussein (2015). Acylphloroglucinol derivatives from the South African Helichrysum niveum and their biological activities, Molecules 20, 17309-17324.

[10] A. Nostro, G. Bisignano, M. A. Cannatelli, G. Crisafi, M. P. Germano and V. Alonzo (2001).Effects of Helichrysum italicum extract on growth and enzymatic activity of Staphylococcus aureus, Int. J. Antimic. Agents 17, 517-520.

[11] P. A. R. Ramanoelina and J. R. Bianchini (1992). Chemical composition of the essential oil of Helichrysum bractieferum, J. Essent. Oil Res. 4, 531-532.

[12] R. Puerta, M. D. Garcia, M. T. Saenze and A. M. Gil (1993). Analysis of the essential oil from Helichrysum picardii, Planta Med. 59, 94-95.

[13] I. B. Chinou, V. Roussis, D. Perdetzoglou, O. Tzakou and A. Loukis (1997). Chemical and antibacterial studies of Helichrysum species of Greek origin, Planta Med. 63, 181-183.

[14] I. B. Chinou, V. Roussis, D. Perdetzoglou and A. Loukis (1996). Chemical and biological studies on two Helichrysum species of Greek origin, Planta Med. 62, 377-379.

[15] K. H. C. Baser, B. Demirci and N. Kirimer (2002). Compositions of the essential oils of four Helichrysum species from Madagascar, J. Essent. Oil Res. 14, 53-55.

[16] A. C. U. Lourens, D. Reddy, K. H. C. Baser, A. M. Viljoen and S. F. Van Vuuren (2004). In vitro biological activity and essential oil composition of four indigenous South African Helichrysum species, J. Etnopharmacol. 95, 253-258.

[17] M. M. El-Olemy, A. J. Al-Rehaily, O. A. Albishi, J. S. Mossa, B. Demirci and K. H. C. Baser (2005). Composition of the essential oil of Helichrysum forsskahlii (Gmel) Hilliard et Burt., J. Essent. Oil Res. 17, 112-116.

[18] B. Öztürk, G. Özek, T. Özek and K. H. C. Baser (2014). Chemical diversity in volatiles of Helichrysum plicatum DC. subspecies in Turkey, Rec. Nat. Prod. 8(4), 373-384.

[19] K. Polatoglu, B. Demirci, I. Calis and K. H. C. Baser (2016). Essential oil composition of Helichrysum conglobatum from Cyprus, Nat. Prod. Commun. 11(10), 1521-1522.

[20] O. Elkıran, E. Bagcı and H. Evren (2013). Composition of the essential oil of endemic Helichrysum noeanum Boiss. (Asteraceae) growing wild in Turkey, Asian J. Chem. 25(14), 7949-7951.

[21] M. Babota, A. Mocan, L. Vlase, O. Crisan, I. Ielciu, A.-M. Gheldiu, D. C. Vodnar, G. Crişan and R. Paltinean (2018). Phytochemical analysis, antioxidant and antimicrobial activities of Helichrysum arenarium (L.) Moench. and Antennaria dioica (L.) Gaertn. flowers, Molecules 23, 409. doi:10.3390/molecules23020409.

[22] G. Ruberto, D. M. Biondi, C. Barbagallo, R. Meli and F. Savoca (2002). Constituents of stem and flower oils of Helichrysum litoreum Guss., Flavour Fragr. 17, 46-48. 
[23] V. Roussis, M. Tsoukatou, P. V. Petrakis, I. Chinou, M. Skoula and J. B. Harborne (2000). Volatile constituents of four Helichrysum species growing in Greece, Biochem. Systemat. Ecol. 28, 163-175.

[24] M. M. Staver, I. Gobin, I. Ratkaj, M. Petrovic, A. Vulinovic, M. Dinarina-Sablic and D. Broznic (2018). In vitro antiproliferative and antimicrobial activity of the essential oil from the flowers and leaves of Helichrysum italicum (Roth) G. Don growing in central Dalmatia (Croatia), J. Essent. Oil Bearing Plant. 21(1), 77-91,

[25] O. Elkıran, E. Bagcı and H. Evren (2013). Composition of the essential oil of endemic Helichrysum noeanum Boiss. (Asteraceae) growing wild in Turkey, Asian J. Chem. 25(14), 7949-7951.

[26] S. Bingol and B. Cubukcu (1984). Flavonoids of Helichrysum noeanum Boiss. (Asteraceae), Sci. Pharmaceut. 52(2), 127-130.

[27] B. Tepe, M. Sokmen, H. A. Akpulat and A. Sokmen (2005). In vitro antioxidant activities of methanol extracts of four Helichrysum species from Turkey, Food Chem. 90(4), 685-689.

[28] H. E. Eroğlu, A. Aksoy, E. Hamzaoğlu, Ü. Budak and S. Albayrak (2009). Cytogenetic effects of nine Helichrysum taxa in human lymphocytes culture, Cytotechnol. 59, 65-72.

[29] A. Güner, S. Aslan, T. Ekim, M. Vural and M.T. Babaç (2012). List of Turkish flora (Vascular Plants). Nezahat Gökyigit Botanik Bahcesi ve Flora Arastırmaları Dernegi Yayını. Istanbul, Türkiye.

[30] R. P. Adams (2007). Identification of essential oil components by Gas Chromatography/Mass Spectrometry. Allured Publ. Corp, Carol Stream, IL.

[31] D. H. Hochmuth (2008). MassFinder-4, Hochmuth Scientific Consulting, Hamburg, Germany.

[32] F. W. McLafferty and D. B. Stauffer (1989). The Wiley/NBS registry of mass spectral data, J. Wiley and Sons: New York, USA.

[33] J. Curvers, J. Rijks, C. Cramers, K. Knauss and P. Larson (1985). Temperature programmed retention indexes: calculation from isothermal data. Part 1: Theory, J. High Resolut. Chrom. 8, 607-610.

[34] F. Abak, G. Yildiz, V. Atamov and M. Kurkcuoglu (2018). Composition of the essential oil of Salvia montbretii Benth. from Turkey, Rec. Nat. Prod. 12(5), 426-431.

[35] V. I. Babushok, P. J. Linstrom and I. G. Zenkevich (2011). Retention indices for frequently reported compounds of plant essential oils, J. Phys. Chem. Ref. Data. 40.

[36] A. Kaya, M. Dinc, S. Dogu and B. Demirci (2017). Compositions of essential oils of Salvia denophylla, Salvia pilifera, and Salvia viscosa in Turkey, J. Essent. Oil Res. 29(3), 233-239.

[37] M. Kurkcuoglu, N. Tabanca, A. Ali, I. A. Khan, A. Duran and K. H. C. Baser (2018). Chemical composition of a new taxon, Seseli gummiferum subsp. ilgazense, and its larvicidal activity against Aedes aegypti, Rec. Nat. Prod. 12 (2), 184-189.

[38] H. E. Temel, B. Demirci, F. Demirci, F. Celep, A. Kahraman, M. Dogan and K. H. C Baser (2016). Chemical characterization and anticholinesterase effects of essential oils derived from Salvia species, $J$. Essent. Oil Res. 28, 322-331.

[39] A. F. Barrero, J. E. Oltra, J. Altarejos, A. Barragan, A. R. Lara and R. Laurent (1993). Minor components in the essential oil of Juniperus oxycedrus L. wood, Flavour Frag. J. 8, 185-189.

[40] M. Kurkcuoglu, A. Abdel-Megeed, and K. H. C. Baser (2013). The composition of Taif rose oil, $J$. Essent. Oil Res. 25(5), 364-367.

[41] S. Kucuk, M. Kurkcuoglu and K. H. C. Baser (2018). Morphological, indumentum and chemical characteristics and analysis of the volatile components of the flowers of Rhododendron ponticum $\mathrm{L}$. subsp. ponticum (Ericaceae) of Turkish origin, Rec. Nat. Prod. 12(5), 498-507.

[42] D. O. Moronkola, I. A. Ogunwande, K.H.C. Baser, T. Ozek and G. Ozek (2009). Essential oil composition of Gmelina arborea Roxb.,Verbenaceae, from Nigeria, J. Essent. Oil Res. 21(3), 264-266.

[43] B. Ozturk, G. Ozek, T. Ozek and K. H. C. Baser (2014). Chemical Diversity in volatiles of Helichrysum plicatum DC. subspecies in Turkey, Rec. Nat. Prod. 8(4), 373-384.

[44] A. Ali, N. Tabanca, M. Kurkcuoglu, A. Duran, E. Blythe, I. A. Khan and K. H. C. Baser (2014). Chemical composition, larvicidal, and biting deterrent activity of essential oils of two subspecies of Tanacetum argenteum (Asterales: Asteraceae) and individual constituents against Aedes aegypti (Diptera: Culicidae), J. Med. Entomol. 51(4), 824-830.

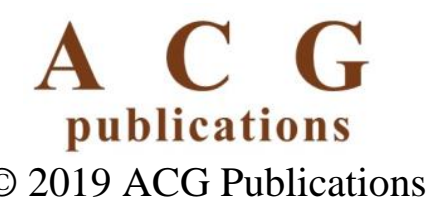

